\title{
THE ELEMENTARY CHARACTERIZATION OF ANTHILL CLAY FOR COMPOSITE MATERIALS AND ADVANCED INDUSTRIAL APPLICATIONS
}

\author{
SURESH ALUVIHARA ${ }^{1 *}$, C.S. KALPAGE ${ }^{1}$, P.W.S.K. BANDARANAYAKE ${ }^{2}$ \\ ${ }^{1}$ Department of Chemical and Process Engineering, University of Peradeniya, Peradeniya, \\ 20400, Sri Lanka, sureshaluvihare@gmail.com \\ ${ }^{2}$ Department of Physics, University of Peradeniya, Peradeniya, 20400, Sri Lanka
}

\begin{abstract}
Anthill clay is a distinct soil/clay genre among common soil types because of the extraordinary stockpiling method. The small particles are carried in and erected an anthill by a small creature that it is called as termite. In generally, clay is a conspicuous raw material for industrial applications greatly and the assay of expediencies of anthill clay for advanced material applications were the prospects of the existing research. Carefully collected anthill clay samples were characterized under the physically and chemically using standard procedures and instruments. The mechanical characteristics of prepared bricks from anthill clays under $8000 \mathrm{C}$ were investigated. As the major outcomes of the existing investigation of raw clays, there were looked to 5.56 of $\mathrm{PH}$ value, $15 \%$ of natural moisture content, gap graded and symmetrically distributed arrangement of grains, $60 \%$ finer particle percentage $(<0.075 \mathrm{~mm})$ according to the weight, composition of $\mathrm{Fe}$, $\mathrm{Ti}$, $\mathrm{Ba}$ and $\mathrm{K}$ based compounds including Fe minerals with large sorption capacity for other metals. In addition that $25 \%$ of water absorption, 2.62 of bulk specific gravity, $65 \%$ of apparent porosity, 21 Mpa compressive strength and 0.4 Mpa splitting tensile strength were observed with respect to the bricks which were prepared from the anthill clay. Based on the behaviors of such anthill clay it should be an influential material in the advanced material manufacturing in the industrial purposes such as the water treatments, rigid materials, catalysts and refractors.
\end{abstract}

Keywords: anthill clay, physico-chemical characteristics, advanced industrial applications

\section{INTRODUCTION}

Anthill clay is some sort of different clay variety among well known clay species because of the availability of anthill clay. When considering the origin and formation of anthill clay, the initial factors would be similar with the origins of other clay types such as the transportation and accumulation of sediments due to the rain, wind or gravitation force. The pattern of availability is exactly significant because the anthill is prepared by termites using some of available clay type at around the location. Therefore, the characteristics of the anthill clay would be differing based upon the location. As the literature review of the existing industrial uses of other different clay varieties the following uses could be highlighted as the dominant examples (Maina et al., 2015): pottery industries; ceramic and porcelain industry; manufacturing of building materials.

Since the ancient applications were limited for mechanical applications, currently most of new innovations are being processed regarding most of different clay varieties beyond the primary uses of such clays. Among the well-known modern investigations of clays, applications of the industry of water treatment gained high benefits because the water pollution has been detected as a huge matter in the current world (Adamu et al., 2010). According to the literature reviews on the recent researches of the developments of following important approaches were emphasized as the important outcomes (Maurya et al., 2018): removal of heavy metals from the contaminated/polluted water; removal of some pathogens from contaminated water; removals of unnecessary or hazardous ions from waste water.

According to the working explanations of the most of above tasks, the main working process is adsorption, a chemical process which occurs due to the electrostatic forces of both attracting compound and attaching compound (Mahandrimanana and Joseph, 2013).

https://doi.org/10.24264/icams-2020.I.2 
Therefore, the adsorption process is a surface-based chemical process and does not involve penetration of the attached material.

Clay is usually known as a group of minerals with the silicate minerals and some of ferrous minerals (Adamu et al., 2010). Due to the diversities in the chemical compositions, clays have obtained a series of distinguished properties including some advanced characteristics such as the refractory properties, adsorption capacities and ion exchanging properties (de Oliveira et al., 2016).

Anthill clay is a specific clay type which is not enclosed as an industrially applicable material since it may have some of extraordinary characteristics. In the existing research, there were expected to investigate the primary physic-chemical characteristics of a selected unknown type of anthill clay and also to investigate some mechanical properties of prepared brick from such anthill clays.

\section{MATERIALS AND METHODOLOGY}

The raw anthill clay samples were collected from Matale region by following important precautions to maintain the accuracy of the results of further analysis - to be collected in a dry climatic occasion; usage of well cleaned non-metallic tools; storage in polythene bags. The important physical-chemical characteristics of raw anthill clays were investigated using standard methods and instruments as discussed in Table 1.

Table 1. Investigations of the physical-chemical characterizations of the clays

\begin{tabular}{cc}
\hline Physical-Chemical Characteristic & Instruments and Methodology \\
\hline Acidity $(\mathrm{pH})$ & $\begin{array}{c}\text { The } \mathrm{pH} \text { value of a prepared clay solution (distilled water) was } \\
\text { measured using a digital } \mathrm{pH} \text { meter }\end{array}$ \\
The weight loss of some selected natural clay portion and \\
the dry weight of the sample clay portion \\
Natural Moisture Content & $\begin{array}{c}\text { Mechanical sieve analysis (dry sieve analysis) of anthill clay } \\
\text { using the size range } 2 \mathrm{~mm}-0.037 \mathrm{~mm} \text { and }<0.037 \mathrm{~mm}\end{array}$ \\
Particle Size Distribution & The representative clay sample was dissolved out in distilled \\
Clay Portion & water on 0.075mm sieve (wet sieve analysis) \\
(Finer Portion $<0.075 \mathrm{~mm})$ & X-ray fluorescence (XRF) spectrometer \\
Elemental Chemical Composition &
\end{tabular}

The following definitions and equations were used in the computation of the important properties of raw clays (Verma et al., 2017).

Moisture content $=\left\{\left(\mathrm{W}_{\mathrm{I}}-\mathrm{W}_{\mathrm{F}}\right) / \mathrm{W}_{\mathrm{I}}\right\} * 100 \%$

$\mathrm{W}_{\mathrm{I}}=$ Initial weight of raw clay sample/ $\mathrm{g}$

$\mathrm{W}_{\mathrm{F}}=$ Final weight of dried clay sample/ $\mathrm{g}$

Coarse portion $=\left(\mathrm{W}_{\mathrm{C}} / \mathrm{W}_{\mathrm{D}}\right) * 100 \%$

Finer portion $=\left\{\left(\mathrm{W}_{\mathrm{D}}-\mathrm{W}_{\mathrm{C}}\right) / \mathrm{W}_{\mathrm{D}}\right\} * 100 \%$

$\mathrm{Wc}=$ Dry weight of the coarse portion $/ \mathrm{g}$

$\mathrm{W}_{\mathrm{D}}=$ Weight of dried initial clay sample/g

According to the dry sieve analysis results of clays, the particle size distribution curve was plotted on a semi-logarithm sheet, recording readings in accordance with literature (Umoru et al., 2015):

- $\quad \mathrm{D}_{10} \rightarrow \mathrm{D}_{75}=$ Diameter corresponding to $10 \% \rightarrow 75 \%$ finer percent in the particle size distribution curve/mm 
Based upon above results, the important grain size parameters of the clay were computed using the given equations and definitions (Dewangan et al., 2015).

Effective size $=\mathrm{D}_{10}$

$\mathrm{C}_{\mathrm{u}}=\mathrm{D}_{60} / \mathrm{D}_{10}$

$\mathrm{C}_{\mathrm{u}}=$ Uniformity coefficient

$\mathrm{C}_{\mathrm{c}}=\left(\mathrm{D}_{30}\right)^{2} /\left(\mathrm{D}_{60} * \mathrm{D}_{10}\right)$

$\mathrm{C}_{\mathrm{u}}=$ Coefficient of gradation

$\mathrm{S}_{0}=\left(\mathrm{D}_{75} / \mathrm{D}_{25}\right)^{1 / 2}$

$\mathrm{S}_{0}=$ Sorting coefficient

Average grain size $=\mathrm{D}_{50}$

$\mathrm{S}_{\mathrm{K}}=\left(\mathrm{D}_{25} * \mathrm{D}_{75}\right) / \mathrm{D}_{50}$

$\mathrm{S}_{\mathrm{K}}=$ Skewness

The representative clay portion sample was dried for 24 hours at the temperature of $110^{\circ} \mathrm{C}$ and analyzed using an X-ray fluorescence (XRF) spectrometer (Cultrone et al., 2004). A set of bricks were manufactured from this anthill clay under following conditions:

- Sizes were $1.5 \mathrm{~cm}$ x $6 \mathrm{~cm} \times 10 \mathrm{~cm}$ in moulds;

- The firing temperature was $800^{\circ} \mathrm{C}$ in muffle furnace;

- The firing time was about 12 hours.

The compressive strengths and splitting tensile strengths of manufactured bricks were tested using the universal tensile strength testing machine.
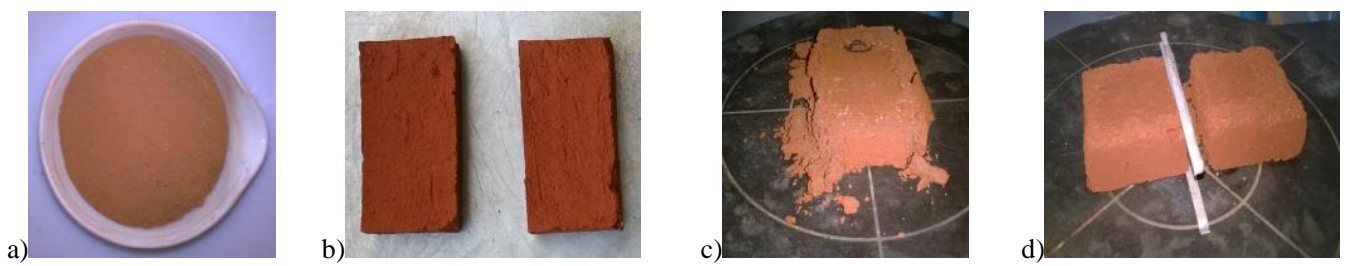

Figure 1. a) Anthill clay sample; b) Manufactured anthill clay bricks; c) Breaking the structure of bricks under compressive load and (d) under splitting tensile load

In the computation of the compressive strengths and splitting tensile strengths of bricks, following equations and definitions were used (Abu Bakar et al., 2018).

Compressive Strength $=\mathrm{P}_{\mathrm{C}} / \mathrm{A}$

$\mathrm{P}_{\mathrm{C}}=$ Applied compressive load in the failure of the structure $(\mathrm{N})$

$A=$ Surface area of the bed surface of the brick $\left(\mathrm{m}^{2}\right)$

Splitting Tensile Strength $=2 \mathrm{P} /\left(\pi^{*} \mathrm{H}^{*} \mathrm{~L}\right)$

$\mathrm{P}=$ Maximum applied load at the failure of the structure $(\mathrm{N})$

$\mathrm{H}=$ Distance between two edges (bridges) (m)

$\pi=$ Constant $(3.142)$

$\mathrm{L}=$ Splitting length $(\mathrm{m})$

Bulk densities and porosities of manufactured bricks were tested as discussed in Table 2 (Umoru et al., 2015). 
Table 2. Investigation of the mechanical properties of manufactured bricks from anthill clay

\begin{tabular}{cc}
\hline Mechanical Property of Bricks & Methodology \\
\hline Water Absorption & The weight difference between the weight of dry brick and the \\
weight of wetted brick & (24 hours immersion period in water) \\
Bulk Density & $\begin{array}{c}\text { The ratio between the dry mass of the brick and occupied } \\
\text { volume }\end{array}$ \\
Porosity & The ratio between the volume of absorbed water and the \\
volume of the brick
\end{tabular}

The above-mentioned characteristics of clay were computed using following equations and definitions based upon the obtained results.

Water Absorption $=\left\{\left(\mathrm{W}_{\mathrm{W}}-\mathrm{W}_{\mathrm{D}}\right) / \mathrm{W}_{\mathrm{D}}\right\} * 100 \%$

$\mathrm{W}_{\mathrm{D}}=$ Weight of the dried brick /g

$\mathrm{W}_{\mathrm{W}}=$ Weight of the wetted brick/g

Bulk Density $=\mathrm{W}_{\mathrm{D}} / \mathrm{V}$

$\mathrm{W}_{\mathrm{D}}=$ Dried weight of the brick $/ \mathrm{g}$

$\mathrm{V}=$ Volume of the brick $/ \mathrm{cm}^{3}$

Porosity $=\left\{\left(\mathrm{W}_{\mathrm{W}^{-}} \mathrm{W}_{\mathrm{D}}\right) / \rho * \mathrm{~V}\right\} * 100 \%$

$\mathrm{W}_{\mathrm{W}}=$ Wetted weight of the brick $/ \mathrm{g}$

$\mathrm{W}_{\mathrm{D}}=$ Dried weight of the brick /g

$\rho=$ Density of the absorbed fluid by the brick (absorbate) $/ \mathrm{gcm}^{-3}$ (For water, $\rho=1 \mathrm{gcm}^{-3}$ )

$\mathrm{V}=$ Volume of the brick $/ \mathrm{cm}^{3}$

\section{RESULTS AND DISCUSSION}

The obtained results for the physic-chemical properties of anthill clays have been shortlisted in the Table 3.

Table 3. Physical-chemical characteristics of anthill clay

\begin{tabular}{cc}
\hline Physical-Chemical Characteristic & Result \\
\hline Acidity / $(\mathrm{pH})$ & 5.56 \\
Natural Moisture Content / (\%) & $\sim 15$ \\
Weight Percentage of Coarse Particles (Sand) / (\%) & $\sim 40$ \\
Weight Percentage of Finer Particles (Clay and Silt) / (\%) & $\sim 60$ \\
\hline
\end{tabular}

According to the acidity of such clay, it is categorized as weak acidic clay because the $\mathrm{pH}$ value is between 5.5-7.0. The acidity of soil will be much considered in the agricultural and plantation purposes. The natural moisture content is a primary indicator for some sort of physic-chemical characteristics such as the porosity although it is impossible to use that one as a factor for such characteristics because it is not depending only on the characteristics of clay/soil and the natural moisture content is also depended on the environmental conditions such as the climatic conditions of the location (Mahandrimanana and Joseph, 2013). 
The finer portion was obtained as $\sim 60 \%$ according to the weight procentage which is indicated the characteristics of plasticity and cohesiveness of such soil/clay and would be a combination of clay, silt and ultrafine clay.

The elemental chemical composition of anthill clay is given in the Table 4 .

Table 4. Elemental composition of anthill clay

\begin{tabular}{ccc}
\hline Atomic Number & Element & Content $(\%)$ \\
\hline 26 & Ferrous & 82.08 \\
22 & Titanium & 4.84 \\
56 & Barium & 0.79 \\
19 & Potassium & 12.28 \\
\hline
\end{tabular}

According to the above results, it seems that the major composed metallic element is $\mathrm{Fe}$ with other trace metallic elements such as $\mathrm{Ti}$, $\mathrm{Ba}$ and $\mathrm{K}$ may be in the form of their oxides namely as $\mathrm{Fe}_{2} \mathrm{O}_{3}, \mathrm{TiO}_{2}, \mathrm{BaO}$ and $\mathrm{K}_{2} \mathrm{O}$. In the discussion of the common behaviors of such elements with their different forms, the Fe could be identified as a non-hazardous element which is also becoming a part of most of minerals. Usually the Fe minerals were identified as strong sorption or adsorption materials for some other metals such as the heavy metals in the recent researches with the applicability of clays for multi-purposes (Saat et al., 2009). Therefore, this anthill clay could be further developed or used in the waste water treatments especially for the waste water with some higher concentrations of heavy metals and also higher concentration of pathogens. The element $\mathrm{Ba}$ is also a non-toxic element although the $\mathrm{Ba}^{2+}$ is highly toxic for human body, if it is inserted into the digest system as a containable material in aqueous solutions because $\mathrm{Ba}^{2+}$ solutions may not be dissolved in hydrochloric acid and ultimately it is possible to cause some stomach problems (Baranowski et al., 2002). Therefore, it is most important the investigation of the leaching of $\mathrm{Ba}^{2+}$ into water, if this clay is selected for the water purification material. Also the element $\mathrm{K}$ is identified as a non-toxic element. But it is possible to find some effect on the alkalinity of the water, if this clay type is using in the water purifications because $\mathrm{K}$ is an alkaline metal. Alternatively, the $\mathrm{K}^{+}$has been identified as an exchangeable ion that able to replace for another cation. Therefore, it is possible to find some advanced ion exchanging applications in chemical water treatment processes. Ion exchanging is an advanced chemical treatment method for waste water to remove some undesirable ions from the waste water and to replace with some desirable ions (Maurya et al., 2018). In addition that there was not found any heavy metal nor toxic element in anthill clay under this investigation. As a further recommendation, it is possible to suggest some advanced chemical compositional analysis method which is namely as Neutron Activation Analysis (NAA) for better descriptive results. The retained clay weights on each sieve and percent finer with respect to each sieve are shortlisted in the Table 5.

The majority was obtained by the particles in the size ranges of $0.25 \mathrm{~mm}-0.5 \mathrm{~mm}$ according to the weight of the clay sample. The retained weight percentages on sieves are some better readings for the investigation of the particle size distribution. The majority of weights in large sieves indicate the coarse grained soils and the majority of weights in finer sieves indicate the fine grained soil (Verma et al., 2017).

Table 5. Particle size distribution of anthill clay (grain sizes)

\begin{tabular}{ccccc}
\hline $\begin{array}{c}\text { Sieve Size } \\
(\mathrm{mm})\end{array}$ & $\begin{array}{c}\text { Weight retained } \\
\text { on each sieve }(\mathrm{g})\end{array}$ & $\begin{array}{c}\text { Percentage of } \\
\text { weight retained }(\%)\end{array}$ & $\begin{array}{c}\text { Cumulative percentage } \\
\text { of weight retained }(\%)\end{array}$ & $\begin{array}{c}\text { Percent } \\
\text { Finer }(\%)\end{array}$ \\
\hline 2 & 0.02 & 0.04 & 0.04 & 99.96 \\
0.5 & 10.34 & 20.32 & 20.36 & 79.64 \\
\hline
\end{tabular}

https://doi.org/10.24264/icams-2020.I.2 
The Elementary Characterization of Anthill Clay for Composite Materials and Advanced Industrial Applications

\begin{tabular}{ccccc}
\hline \hline \multicolumn{1}{c}{$\begin{array}{c}\text { Pieve Size } \\
(\mathrm{mm})\end{array}$} & $\begin{array}{c}\text { Weight retained } \\
\text { on each sieve }(\mathrm{g})\end{array}$ & $\begin{array}{c}\text { Percentage of } \\
\text { weight retained }(\%)\end{array}$ & $\begin{array}{c}\text { Cumulative percentage } \\
\text { of weight retained }(\%)\end{array}$ & $\begin{array}{c}\text { Percent } \\
\text { Finer }(\%)\end{array}$ \\
\hline 0.25 & 15.61 & 30.68 & 51.04 & 48.96 \\
0.149 & 12.39 & 24.35 & 75.39 & 24.61 \\
0.074 & 3.91 & 7.68 & 83.08 & 16.92 \\
0.037 & 7.86 & 15.45 & 98.53 & 1.47 \\
$<0.037$ (pan) & 0.75 & 1.47 & 100 & 0.00 \\
\hline
\end{tabular}

The plotted particle size distribution curve of anthill clay is shown in the Figure 9.

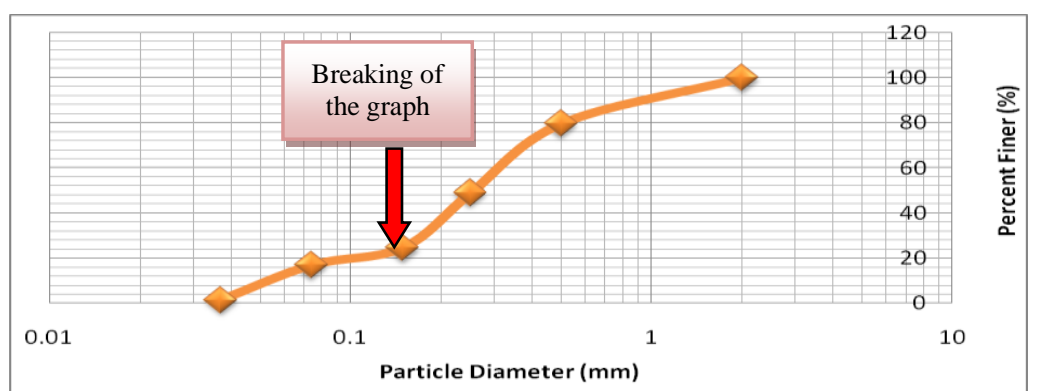

Figure 9. Particle size distribution curve of anthill clay

When considering the shape of the graph (curve), it seems the appearance of the particle size distribution curve of a gap graded clay/soil because the slope (flattened slope) of the graph was deviated from the continuous pattern and a concave shape was observed at the middle part of the graph. Those observations indicate the presence of particles in different sizes since lack of any sequence - Table 6 (Dewangan et al., 2015).

Table 6. Important readings from the particle size distribution curve

\begin{tabular}{ccccccc}
\hline Reading & $\mathrm{D}_{10}(\mathrm{~mm})$ & $\mathrm{D}_{25}(\mathrm{~mm})$ & $\mathrm{D}_{30}(\mathrm{~mm})$ & $\mathrm{D}_{50}(\mathrm{~mm})$ & $\mathrm{D}_{60}(\mathrm{~mm})$ & $\mathrm{D}_{75}(\mathrm{~mm})$ \\
\hline Value & 0.051 & 0.146 & 0.175 & 0.25 & 0.295 & 0.425 \\
\hline
\end{tabular}

Based upon the above important readings, the following important parameters were computed and interpreted as the Table 7.

Table 7. Important parameters regarding the grain sizes of clay

\begin{tabular}{ccccccc}
\hline $\begin{array}{c}\text { Type } \\
\text { of } \\
\text { Clay }\end{array}$ & $\begin{array}{c}\text { Effective } \\
\text { Size } \\
\mathrm{D}_{10}(\mathrm{~mm})\end{array}$ & $\begin{array}{c}\text { Uniformity } \\
\text { Coefficient } \\
\mathrm{C}_{\mathrm{u}}\end{array}$ & $\begin{array}{c}\text { Coefficient } \\
\text { of Gradation } \\
\mathrm{C}_{\mathrm{c}}\end{array}$ & $\begin{array}{c}\text { Sorting } \\
\text { Coefficient } \\
\mathrm{S}_{0}\end{array}$ & $\begin{array}{c}\text { Average } \\
\text { Grain Size } \\
\mathrm{D}_{50}(\mathrm{~mm})\end{array}$ & $\begin{array}{c}\text { Skewness } \\
\mathrm{S}_{\mathrm{K}}(\mathrm{mm})\end{array}$ \\
\hline $\begin{array}{c}\text { Anthill } \\
\text { Clay }\end{array}$ & 0.051 & 5.78 & 2.04 & 1.71 & 0.25 & 0.248 \\
\hline
\end{tabular}

The effective size $\left(\mathrm{D}_{10}\right)$ of a clay or soil is much useful indicator for the drainage and hydraulic conductivity of such clay or soil. If the effective size $\left(D_{10}\right)$ is too diminutive, the hydraulic conductivity will also be reduced. Therefore, the effective size $\left(D_{10}\right)$ of a clay or soil could be considered as the primary characteristic which is related with the permeability of such clay or soil. When the selecting this clay type for some water filtration applications the hydraulic conductivity would be an important factor because the filtration time is depending on the hydraulic conductivity. Apart from the 
effective size $\left(D_{10}\right)$, the shapes of the clay particles play a dominant role on the hydraulic conductivity. If the clay/soil is consisted with large amount of irregular shaped particles, the hydraulic conductivity may be increased. Usually the effective size $\left(D_{10}\right)$ of a soil or clay is using as a comparable parameter when it is available a few of different clay species to select one more uses (Verma et al., 2017).

When considering $g$ the uniformity coefficient $\left(\mathrm{C}_{\mathrm{u}}\right)$ of anthill clay, it is more close to 6. That result indicates the well graded clay type because for well graded clays/soils the uniformity coefficient $\left(\mathrm{C}_{\mathrm{u}}\right)$ is at least 6 . Besides, parameter coefficient of gradation $\left(\mathrm{C}_{\mathrm{c}}\right)$ also indicates the well grading soil/clay type because the obtained value is between 1 and 3. The sorting coefficient $\left(\mathrm{S}_{0}\right)$ is an indicator regarding the sorting of particles (grains) in the soil/clay and the higher sorting coefficient $\left(\mathrm{S}_{0}\right)$ values indicate the well sorted soils/clay (Dewangan et al., 2015).

The average grain size $\left(\mathrm{D}_{50}\right)$ and skewness $\left(\mathrm{S}_{\mathrm{K}}\right)$ are the statistical parameters regarding the particle size distribution of a soil/clay. The average grain size $\left(\mathrm{D}_{50}\right)$ could be used as a single representative value for the sizes of grains in some of a soil/clay. In some coarse grained soils, the average grain size $\left(D_{50}\right)$ values would be higher. According to the obtained value for the skewness $\left(\mathrm{S}_{\mathrm{K}}\right)$, it is found more symmetrical distribution of grains because the result was appeared in the range of 0.10-0.30 (Verma et al., 2017). The obtained results for the mechanical characterizations of anthill clay bricks are shown in Table 8.

Table 8. Mechanical characteristics of anthill clay bricks

\begin{tabular}{cc}
\hline Mechanical Characteristic & Result \\
\hline Water Absorption (\%) & 25 \\
Bulk Density $\left(\mathrm{gcm}^{-3}\right)$ & 2.62 \\
Porosity $(\%)$ & $\sim 65$ \\
Compressive Strength (MPa) & 21 \\
Splitting Tensile Strength (MPa) & 0.4 \\
\hline
\end{tabular}

According to the obtained results for the mechanical characterization of bricks, the average water absorption was detected as $\sim 25 \%$ with respect to the weight. The water absorption is an indicator about the porosity, permeability and the mechanical strengths of the structure (Vodounon et al., 2019).

The bulk density interprets some concepts regarding the density of particles whether they are heavier particles or lighter particles.

The porosity is an important characteristic regarding the applications of water treatment because the high porosity provides a large contact surface area for both water and clay which is an essential factor for the advanced chemical process "adsorption", by means of which some unnecessary components are recovered or removed from some liquid or gas compound onto the surface of some other solid compound, a process is frequently applicable in the industry of waste water treatment especially to remove some heavy metals and pathogens.

The adsorption capacity of some solid material would be varied with the properties of materials (Baranowski et al., 2002).

When considering the mechanical strengths of bricks, there were found the strengthen structure against relatively higher splitting tensile loads and higher compressive loads. The strengths of the brick structure are also depended on the porosity of structure. Therefore, the anthill clay could be further developed for some hard uses in the pure form or as a composite material (Kipsanai et al., 2017).

https://doi.org/10.24264/icams-2020.I.2 


\section{CONCLUSION AND RECOMMENDATIONS FOR FUTURE WORKS}

According to the obtained results, there were observed the gap graded clay with $\sim 60 \%$ of finer weight percentage with majority of Fe compounds without having non toxic elements and the strengthen structure against huge loads. Based on the behaviors of such anthill clay it should be an influential material in the advanced material manufacturing in the industrial purposes such as the water treatments based on adsorption and ion exchanging, rigid materials, catalysts and refractory materials. Meanwhile the entire compositional analysis of the anthill clays using some advanced analytical method such as Neutron Activation Analysis (NAA) will be recommended as a future research activity.

\section{REFERENCES}

Abu Bakar, B.H., Saari, S. and Surip, N.A. (2018), "Split tensile strength of interlocking compressed earth brick units", Journal of Built Environment, Technology and Engineering, 4, 53-58, https://doi.org/10.1063/1.5005649.

Adamu, M.B. (2010), "Fourier Transform Infrared Spectroscopic Determination of Shale Minerals in Reservoir Rocks", Nigerian Journal of Basic and Applied Science, 18(1), 6-18, https://doi.org/10.4314/njbas.v18i1.56836.

Baranowski, R., Rybak, A. and Baranowska, I. (2002), "Speciation Analysis of Elements in Soil Samples by XRF”, Polish Journal of Environmental Studies, 11(5), 473-482.

Bhattarai, J., Ghale, D.B., Chapagain, Y.P., Narendra, B.B. and Duwal, N. (2018), "Study on the physical and mechanical properties of ancient clay brick samples of Kathmandu valley, Nepal", Tribhuvan University Journal, 32(2), 1-18, https://doi.org/10.3126/tuj.v32i2.24699.

Cultrone, G., Sebastian, E., Elert, K., de la Torre, M.J., Cazalla, O. and Rodriguez-Navarro, C. (2004), "Influence of mineralogy and firing temperature on the porosity of bricks", Journal of the European Ceramic Society, 24, 547-564, https://doi.org/10.1016/S0955-2219(03)00249-8.

de Oliveira, C.I.R., Rocha, M.C.G., da Silva, A.L.N. and Bertolino, L.C. (2016), "Characterization of bentonite clays from Cubati, Paraíba (Northeast of Brazil)", Cerâmica, 62, 272-277, https://doi.org/10.1590/0366-69132016623631970.

Dewangan, P.K., Pradhan, M., and Ramtekkar, G.D. (2015), "Effect of Fragment Size, Uniformity Coefficient and Moisture Content on Compaction and Shear Strength Behavior of Coal Mine Overburden Dump Material", European Journal of Advances in Engineering and Technology, 2(12), 1-10.

Kipsanai, J.J., Namango, S.S., Muumbo, A.M. (2017), “A Study of Selected Kenyan Anthill Clays for Production of Refractory Materials", International Journal of Scientific and Research Publications, 7(9), 169-179.

Mahandrimanana, A. and Joseph, R. (2013), "Physico-Chemical Analysis for Differents Types of Clays Soils in the Areas of Analamanga, Itasy and Vakinankaratra", International Journal of Materials and Chemistry, 3(5), 99-105, https://doi.org/10.5923/j.ijmc.20130305.03.

Maina, E.W., Wanyika, H.J. and Gacanja, A.N. (2015), "Instrumental Characterization of Montmorillonite Clay by FT-IR and XRD from J.K.U.A.T Farm, in the Republic of Kenya", Chemistry and Materials Research, 7(10), 43-49.

Maurya, A., Kesharwani, L. and Mishra M.K. (2018), “Analysis of Heavy Metal in Soil through Atomic Absorption Spectroscopy for Forensic Consideration”, International Journal for Research in Applied Science \& Engineering Technology, 6(6), 1188-1192, https://doi.org/10.22214/ijraset.2018.6173.

Saat, A., Hamzah, Z. and Abu Bakar, Z. (2009), "XRF determination of major elemental contents of clay samples from North-West peninsular Malaysia", Journal of Nuclear and Related Technologies, 6(1), 230-236.

Umoru, C.I., Shuaibu, A.M., Abdullahi, I.N. and Umar, M.U. (2015), "Geotechnical Assessment of Gully Erosion at Ankpa Area, North Central Nigeria", IOSR Journal of Applied Chemistry, 8(12), 36-48.

Verma, S.K, Akhtar, S. and Shrivastava, S. (2017), "Assessment of Particles of Varied Soil by Grain Size Analysis - A Case Study in Jabalpur M.P.”, International Journal of Engineering Research and Application, 7(7), 32-37, https://doi.org/10.9790/9622-0707093237.

Vodounon, N.A., Kanali, C., Mwero, J. and Djima, M.O.A. (2019), "Splitting Tensile Strength, Physical and Durability Properties of Cement Stabilized Earth Block Reinforced with Treated and Untreated Pineapple Leaf Fibre", Journal of Materials Science Research, 8(2), 49-57. 